\title{
Does 'Tight' Monetary Policy Hurt U.S. Exports?
}

\author{
DALLAS S. BATTEN and CLIFTON B. LUTTRELL
}

$\mathrm{T}$

HE competitive position of U.S. exports in foreign commodity markets has deterionated over the past year. Of the reasons proffered, the major one has been the adverse impact of the rising exchange value of the U.S. dollar in foreign currency markets. It is argued that a rising dollar makes U.S. exports less competitive in foreign markets by causing their foreign-currency prices to rise relative to those of commodities produced in other countries. ${ }^{1}$ One sector especially affected is the farm sector. In fact, farm exports are expected to decline in fiscal 1982, the first such decline in 13 years (chart 1 ).

The ultimate "blame" for the dollar's strength has been placed on the Federal Reserve's current "tight" monetary policy stance, that is, its desire to reduce the long-run rate of money growth. ${ }^{2}$ As one noted agricultural economist has remarked:

A tight monetary policy, other things equal, leads to a rise in the value of the dollar and a decline in the competitiveness of the export sector in international markets. An easy monetary policy, on the other hand, leads to a decline in the value of the dollar and increased competitiveness. To put it simply, the trade sectors bear the adjustment of changes in monetary policy, and trade is now important to agriculture. ${ }^{3}$

\footnotetext{
U.S. Department of Agriculture, Agricultural Outlook (March 1982), p. 10, and Agricultural Outlook (August 1981), p. 14. Similar views are found in the press and among academic economists. See, for example, Art Pine, "Strong Dollar, a Point of Pride to Reagan Is Said to Hurt Exports and U.S. Economy," The Wall Street Journal, May 13,1982; G. Edward Schuh, "The Foreign Trade Linkages," in Modeling Agriculture For Policy Analysis in the 1980s, A Symposium Sponsored by the Federal Reserve Bank of Kansas City, September 24-25, 1981, pp. 82-57; "The Mighty Dollar Slans U.S. Trade," Business Week (Apil 12, 1982), pp. $30-32$.

"See Solnuh, "The Foreigu Trade Linkages," p. 84; and Robert G. Chambers and Richard $E$. Just, "An Investigation of the Effect of Monetary Factors on Agriculture, "Journal of Monetary Economics (March 1982), pp. 235-67. There are obviously factors other than monetary growth that induce short-rum exchange rate novements. This article, however, ignores these, focusing solety on the short and long-ram impact of noney growth on exchange rate movements.

"Schuh, "The Foreign Trade Linkages," p. 84.
}

This article assesses the validity of this claim that the reduced competitiveness of U.S. exports is due primarily to the Federal Reserve's monetary policy stance. Specifically, this article focuses on the impact of money growth on inflation and exchange rate movements over both short- and long-run periods to investigate how U.S. exports are affected.

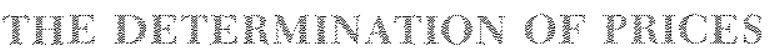 AND TII HONG-RU VIT}

The domestic price level and the exchange rate are determined jointly by the supply of money relative to the amount that individuals desire to hold. The supply of money essentially is determined by the monetary authority. The demand for money (i.e., an individual's desire to hold a portion of his wealth in the form of money) is determined primarily by income, interest rates, prices and price expectations. The equilibrium price level, then, is the one (given the level of income, interest rates and price expectations) that induces individuals to hold the exact quantity of money that monetary authorities are supplying. ${ }^{4}$ Any other price level motivates individuals to attempt to hold more or less money than is being supplied by altering their spending until the price level is driven to its equilibrium level.

Changes in the spending of consumers affect not only domestically produced goods and services, but commodities produced abroad as well. Altered demands for foreign commodities, in turn, produce changes in the U.S. demand for foreign currencies and, as a consequence, changes in the foreign exchange value of the dollar, all other things equal. In other words, a monetary disequilibrium, through its impact on aggregate spending, induces a change in the

\footnotetext{
${ }^{4}$ For simplicity, the analysis here is performed within a static tramework. A dynanic analysis would be couched in terms of growth rates instead of levels of the variables examined.
} 
Chart 1

\section{Market Value of U.S. Agricultural Exports}

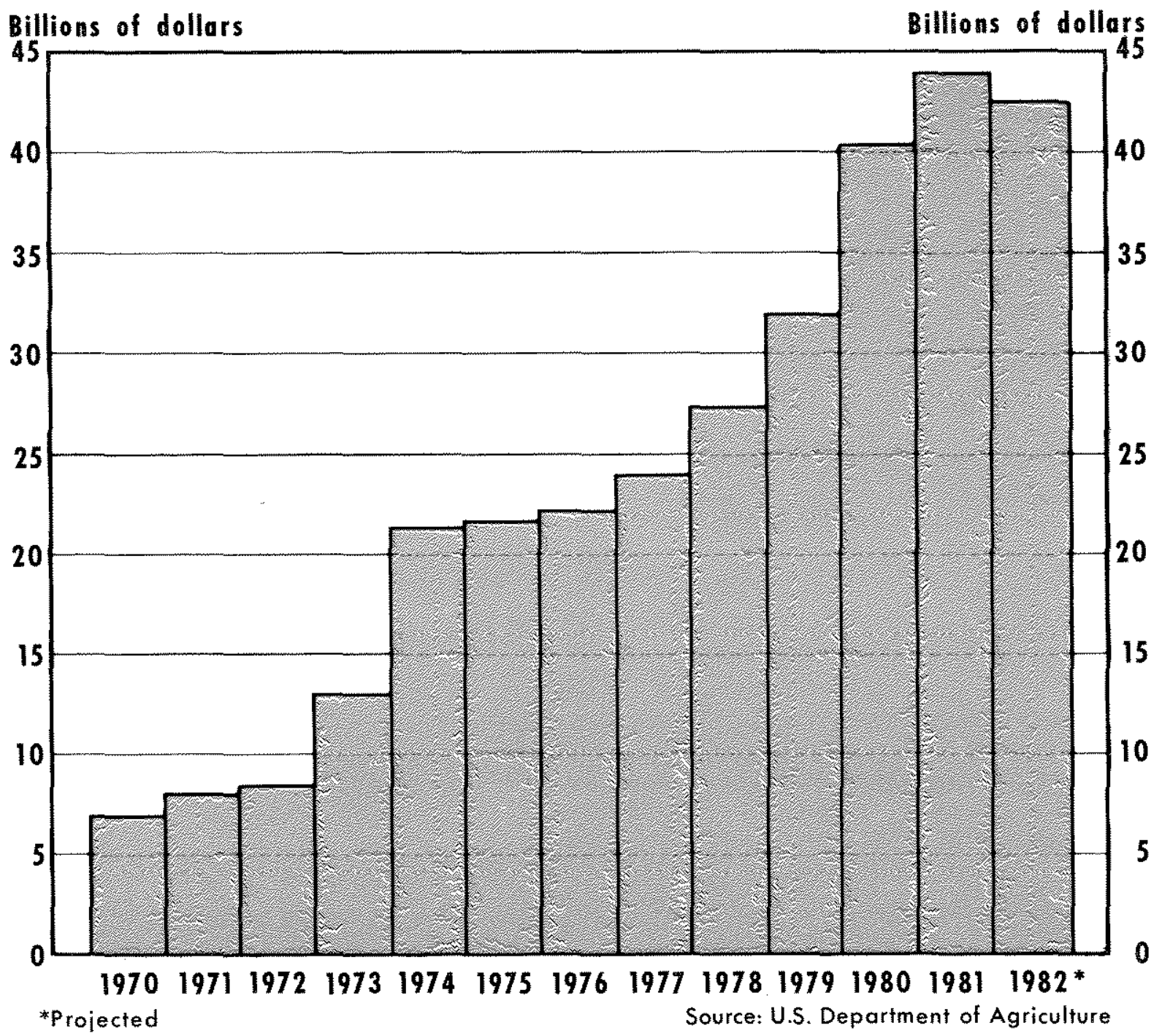

domestic price level and, in the long run, an equal and offsetting change in the exchange rate.

For example, if the supply of money in the United States is less than the amount that individuals desire to hold, both an excess demand for money and an excess supply of goods, services and securities exist at current prices. In an attempt to increase their money holdings to the desired level, individuals decrease their spending on all goods and services, placing downward pressure on domestic prices.

This excess demand for money is associated with decreased spending, not only on domestically pro- duced commodities, but also on commodities produced abroad. The decreased demand for foreign commodities motivates a decrease in the demand for foreign currencies by U.S. importers. With a given supply of foreign currency, the foreign currency value of the dollar will rise.

In the long run, the foreign currency value of the dollar should rise sufficiently to offset the differences between foreign and U.S. prices resulting from the initial excess demand for money. For example, if prices in the United States fall by 10 percent relative to those in Germany, then the Deutsche mak price of the 
dollar should rise by 10 percent, other things equal. ${ }^{5}$ If domestic price level and exchange rate adjustments occur simultaneously and if export prices move with the general price level, the initial excess demand for money will have no long-run effect on either the foreign currency price of U.S. exports or the competitive positions of U.S. exporters in foreign markets. The domestic defation (or, in dynamic terms, disinflation) would exactly offset the impact of the exchange rate appreciation on the foreign-currency price of U.S. goods.

This relationship can be seen quite clearly in chart 2 . This chart displays (a) the trade-weighted foreign currency value of the dollar and (b) the difference between the U.S. rate of inflation (measured by the CPI) and the trade-weighted rate of inflation of the Group of Ten countries (excluding the United States) plus Switzerland. ${ }^{6}$ It is apparent from the chart that, when the rate of domestic inflation in the United States falls relative to that of its major trading partners, the foreign currency value of the dollar rises and vice versa. ${ }^{7}$

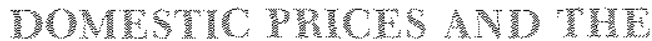 L COWA

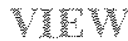

In the short run, producers cannot tell inmediately whether a decrease in aggregate demand (spending) is permanent or just a temporary aberration. Consequently, their initial reaction is to decrease production rather than to lower prices. That is, the excess demand for money initially induces a slowdown in economic activity. Of course, as soon as the dechne in spending has been identified as permanent, producers will lower prices and increase production back to "normal"

\footnotetext{
This conction is known as purchasing power parity. Even though it has been violated freguenty in the short run during the $1970 \mathrm{~s}$. there is no evidence that its useftuness as a condition of longun equilibrium has been mitigated. See Jacob $A$. Frenkel, "The Collapse of Purcbasing Power Parities During the 1970s," European Econonic Rowiew (May 1981), pp. 145-65.

the G-10 countries are Belgim, Canata France, Gemany, laly, Japan, the Netherlants, Sweden, the United Kingdom and the United States. See "Index of the Weighted-Average Exchange Value of the U.S. Dollar: Revision." Feteral Reserve Bulletin (August 1978), p. 700 , for a definition of the weights employed. The calcelated correlation coefficients between (1) the tradeweighted exchange rate and the inflation differential and (2) changes in the trade-weighted exchange rate and changes in the inflation differental are -.892 and -.533 , respectively. Each is statistically significant at the 5 percent level.

${ }^{7}$ Chart 2 is not intended as a proof of purchasing power parity, but sinply a demonstration that the rate of mallation and the exchmge rate are jointly determined by excess noney growth; that is, one does not eause the other.
}

levels. ${ }^{8}$ Thus, the impact of the excess demand for money on output eventually vanishes, leaving only prices permanently affected; however, these long-rum effects are not realized immediately.

On the other hand, the exchange rate responds to this excess demand for money much more rapidly than do the prices of domestic commodities. This occurs because the exchange rate is the relative price of two assets (two currencies); unlike commodity prices, it is determined in highly organized markets that quickly assimilate new information in the same efficient manner as the prices of other financial assets (e.g., stocks and bonds). Therefore, the exchange rate will appreciate before prices of commodities fall sufficiently to eliminate completely the excess demand for money.

During this interim period, U.S. exporters will face a deteriorating competitive position in foreign markets. The foreign currency prices of their products will have risen temporarily because the dollar appreciates before commodity prices fully adjust to the monetary disequilibrium.

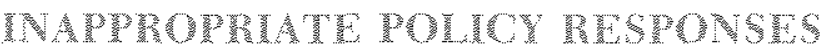

The argument that tighter monetary policy during the past few years has strengthened the dollar and thus reduced the competitiveness of U.S. goods in foreign markets has elicited several proposed policy responses. Among these are increased protectionism, increased subsidization of U.S. exports, a return to an easier monetary policy stance, and large-scale intervention in foreign exchange markets. ${ }^{10}$ Since the inpact of a tighter monetary policy on the competitive position of U.S. exports is only a short-run phenomenon, such policy reactions are inappropriate. ${ }^{11} \mathrm{In}$ particular, policy responses designed to rectify the short-run disequilibrium actually will exacerbate the equilibrating process and, consegnently, lengthen the period of adjustment. Moreover, redirecting domestic

The normal level of production and its patly over time is determined primarily by the avalability and the rate of growth of productive resources.

"For additional support of this argument, see frenkel "The Collapse of Purchasing Power Parilies."

${ }^{10}$ See Pine, "Strong Dollar, a Point of Pride;" "The Mighty Dollar Stams U.S. Trade;" and Chambers and fust, "An lnvestigation,"

"Jacob Frenkel, "Flexible Exchange Rates, Prices, and the Role of News" lessous from the 1970s," Journal of Political Economy (August 1981), pp. 665-705, finds that suh policy responses also may be inappropriate when the short-run deviation from purchasing power parity is motivated by changes in determinants of exchange rates other than money growh. 


\section{Chart 2}

\section{Exchange Rate and Inflation Differential}

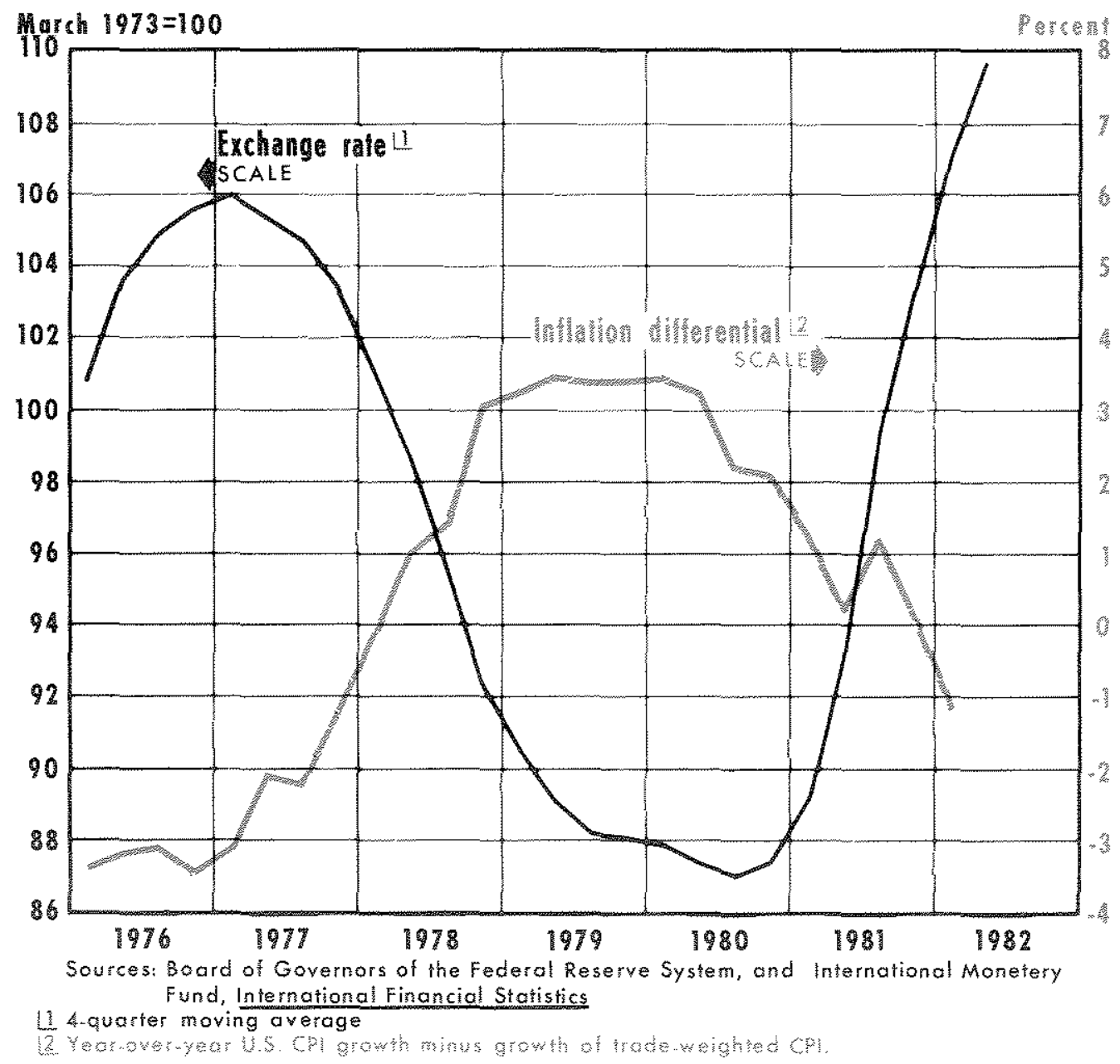

monetary policy (directly or by intervening in foreign exchange markets) to extemal objectives, by definition, subordinates the domestic objectives of monetary policy. Any acceleration of money growth to alleviate the shortam effed of past policy actions ultimately would have no favorable long-run impact on U.S. competiveness in foreign markets. It would result simply in a higher rate of U.S. inflation and a lower exchange value of the dollar.

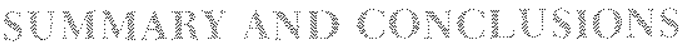

Those who feel that exports have been harmed by a tigh monetary policy have overlooked the fact that the same monetary policy that causes the dollar to strenghen in foreign currency markets also causes the rate of domestic mation to decline relative to that in other countries. These two events (i.e, a ming dollar and falling U.S. inflation exactly of set each other over time. Consequently, foreign importers of U.S. products can purchase fewer dollars with a given amount of their currency but can purchase more U.S. goods with those dollars.

A tighter monetary policy in the United States relative to monetary policies abroad is reflected in the exchange value of the dollar more quickly than in the relative prices of export goods, which reduces temporarily the competitiveness of U,S. exports. Such a poticy, however, has no impact on our long-run competitive position. Consequently, foreign exchange markt intervention, trade restrictions or other policy responses designed to offset this shortm disecuilib. rimm situation are neither necessary nor justified. 